\title{
EŞ'ARÎ KELAMININ DÎNî, HİSSî VE FELSEFî KARAKTERİ ÜZERİNE
}

\author{
Fatih İbiş*
}

\begin{abstract}
Özet
Kelam, ismine kaynaklık teşkil eden cedeli ve nazari yönteminden öte ilahiyat, nübüvvet ve semiyyât olarak belirlenen usûl-ü selâse ile dînî kimliği öne çıkan bir ilimdir. Kelam sahip olduğu dînî ve şer'̂̂ karakterini, temelini oluşturan ve ana konuları olan bu üç esasa borçludur. Nitekim Kelam ilmine verilen "Usûlü'd Dîn" adlandırması onun dînî bir ilim olduğunu göstermesi yanında diğer dînî ilimler arasında asıl konumunda olduğuna da işaret etmektedir. Ancak Kelamın tarihsel süreçte dînî/İslamî olma vasfını ne kadar koruduğu, dînî temel öncüllerine ne kadar bağlı kaldığı meselesi, üzerinde durulması gereken bir konudur. Hem dinin savunucusu hem de diğer dînî disiplinlerin kurucusu olarak tanımlanan bir ilmin metodik sistemi ait olduğu dînî, teolojik sistemden ziyade, doğaya ve felsefî̀ düşünceye ait argümanların içeriğine göre şekilleniyorsa bu ilme yüklenen misyonun ne oranda geçerli olduğu veya bunun ne kadar korunduğu yeniden sorgulanmalıdır. Eş’arî kelamının sosyo-kültürel ve bilimsel etkenlere bağlı dönüşümsel seyrine bakıldığında Kelam tabii ve felsefî açıdan gelişmesine rağmen dînî açıdan kendi köklerinden uzaklaşmıştır. Nitekim Gazali öncesi süreçte Kelam içerik ve yöntemiyle bir tür tabiat teolojisi konumunda iken Gazali'den sonra ortaya çıkan gelenekle felsefî ve metafizik bir teoloji konumuna gelmiştir.
\end{abstract}

Anahtar Kelimeler: İslam, Kelam, duyu, felsefe, Eş’arî kelamı.

\section{On Religious, Sensual and Philosophical Character of Ash`arite Theology}

\begin{abstract}
Kalām was formed as science in the light of jadal (dialectics) and nazar (theoretical methods). It also includes three essential elements known as divinity, propethood and sami yyāt (eschatalogy). Owing to this, Kalām may be defined as religious science. In other words, the religious and legal (shar'iy) characteristics of Kalām owes its existence to these 'three foundations' which were the subject study for the Kalām. In addition to this, Kalām was also called as ' $U s ̦ u l$ al-Dīn' (essentials of religion). Therefore, it may not be wrong to say that it secures its main position among other religious sciences. However, it is important to highlight that how and to what extent kalām remained as 'Islamic and religious science' in its historical development. To be more precise, at the outset, kalām is considered as 'defender of religion' and 'founding father' of religious sciences. Later, it started to deal more heavily with positive and philosophical arguments rather than religious and theological ones. Therefore, authenticity of Kalām's fundamental mission and how it secured its main functions are needed to reconsider to ensure its validity. al-Ash arite theology went through great progress in relation to positive and philosophical arguments during its socio-cultural and intellectual development. As a result, it may not be wrong to say that Ash'arite theology continued to exist distant from its religious roots. As a matter of fact, it can be observed that kalām had its progress towards natural theology prior to al-Ghazzālī. Later, kalām as science transformed into philosophical theology during post al-Ghazzālī period.
\end{abstract}

Keywords: Islām, Kalām, sense, philosophy, Ash 'arite theology

\footnotetext{
*Yrd. Doç. Dr., Pamukkale Üniversitesi İlahiyat Fakültesi, fatihibis@ pau.edu.tr
} 


\section{Giriş}

Kelam ilmi normatif yönüyle diğer İslamî disiplinlere kıyasla kurucu/inşâ̂ mahiyete sahiptir. Temsil ettiği üst kimlik açısından Kelam küllî olması itibariyle kendisi dışındaki cüz' '̂̀ sayılabilecek dînî/ilmî disiplinlerin alt yapısını teşkil eder. ${ }^{1}$ Öyle ki en somut ve içkin varlıktan en soyut ve aşkın Varlığa uzanan anlama çabası, Kelamı diğer ilimlerden daha üst ve üstün bir konuma yerleştirir. "Kelam, alemin gerçekliğini en soyut (en yüksek) derecede ortaya çıkaran bir anlama ve dil düzeyi olduğu için en yüksek Varlı̆̆ fark etmek ve anlamak için en meşru bir ilimdir. "2 Kelam ilmine verilen isimler içinde "Usûlü'd Din” adlandırması bu duruma işaret eden en açık örnektir. Zira Usûlü'd Din tamlaması dinin inanç esaslarını içermesi yanında, bu esasların temellendirilmesi ve savunulması amaciyla yapılan nazari/istidlali dayanakları da içermektedir. Nitekim Teftazani, Nesefi'nin akaidine yazdığg şerhin girişinde Kelam ilmini bu yönüyle ele alarak onu "İslam inanç esaslarının esası" olarak belirlemiştir. ${ }^{3}$ Şerhu'l Akaid'in en önemli muhaşşîlerinden Hayâlî, Teftazani'nin bu tespitini itikadi esasların Kelamın konuları içinde ayrıntılı biçimde incelenmiş olmasına dayanarak açımlar. Hayâlî’ye göre bu durum Kelamı “üssü'l esas” kılarak dinin esası olan Kitap ve sünneti de kuşatan bir konuma getirmiştir. ${ }^{4}$ Aksi takdirde Kelamın tarih gibi nakil ve tasvir yapan bir ilme dönüşmesi, kurucu vasfindan uzaklaşması söz konusudur. Usûlü'd Din kavramının çift kutuplu doğası kelam faaliyetinde birbirini dışlamayan, aksine kapsayan bir diyalektiği ön görmektedir. Kelamın kurucu vasfı da esas itibariyle bu diyalektiğin ikame ve idamesine bağlı olarak gerçekleşmektedir.

\footnotetext{
* Yrd. Doç. Dr., Pamukkale Üniversitesi İlahiyat Fakültesi, fatihibis@pau.edu.tr

${ }^{1}$ Ebu Hâmid Muhammed b. Muhammed el-Gazali, el-Mustasfa, çev. Yunus Apaydın, Klasik Yayınları, İstanbul 2007, I, 8. İzutsu'ya göre Kur'an'ın nüzûlünün tamamlanmasından sonra ortaya çıkan İslamî ilimler içinde Kur'an'ın kavramsal çerçevesine (vokabulari) en sadık kalan ilim Kelamdır. Sembolik mana yoğunluğu nedeniyle Tasavvuf bu çerçeveye uzak, İslam Felsefesi de Yunan düşüncesini Arapçalaştırma ve İslamîleştirme çabasından dolayı en uzak ilimdir. Toshihiko İzutsu, Kur'an'da Allah ve İnsan, çev. Süleyman Ateş, İstanbul Tsz, s. 54.

${ }^{2}$ Burhanettin Tatar, "Kelami Söylemin Monolojik Karakteri”, Tezkire, Sayı. 31, 32, Mart/Haziran 2003, s. 77.

${ }^{3}$ Muslihuddin Mustafa el-Kesteli, Haşiyetü'l Kesteli ala Şerhi'l Akaid, Salah Bilici Kitabevi, İstanbul Tsz, s. 6.

${ }^{4}$ Ahmed Hayâlî, Haşiyetü'l Hayâlî ala Şerhi'l Akaid (Mecmuatü'l Havaşi el-Behiyye ala Şerhi'l Akaidi’n Nesefiyye'nin Kenarında-neşr. Abdülkerim), el-Mektebetü’l İslamiyye, 1390 (h), I, 8.
} 
Görüldüğü üzere bazı kelamcılar tarafından Kelama kendi dışındaki ilmi disiplinlerin yanında aslını teşkil eden temel kaynaklar olan Kur'an ve sünneti de aşan üst bir misyon yüklenmiştir. Ancak Kelamın tarihi gelişim seyrini dikkate aldığımızda, kendisine biçilen bu üstün rolün, girdiği son dönemeçte yani özellikle müteahhir dönemde öne çıkarıldığına tanık olmaktayız. Peki kelam özellikle de Ehl-i sünnet kelamının ana damarlarından birini teşkil eden Eş'arîlik kendisine yüklenen bu misyonu gerçekleştirebilmiş ve tarihi süreçte koruyabilmiş midir? Daha açık soracak olursak mütekellimler, kelamı zihinsel diyalektiğin (cedel) bir gereği olarak "mücerret ve muhayyel” bir kelam olarak mı, yoksa gerçekten Usûlü'd Din isminin gereği olan "muayyen ve muhakkak" bir kelam faaliyeti olarak mı icra etmişlerdir? Kelam tarihini kronolojik bir okumaya tâbi tuttuğumuzda esas itibariyle kelamın yaşadığı metodik ve yapısal değişimi tam olarak görmemiz mümkün değildir. Bu nedenle konunun değișen ana karakterleri üzerinden kelamın tarihi süreç içinde geçirdiği dönüşümler üzerinden tahlil edilmesi gerekmektedir.

\section{Dînî, Hissî ve Felsefî̀ Kelam}

Genellikle Kelam ilmi söz konusu olduğunda akla Gazali ile şekillenen mütekaddim ve müteahhir iki dönem gelir. Halbuki Kelam ilminin nereden nereye geldiği, dînî karakterinden ne tür bir karaktere evrildiğini görmek açısından bu dönemlerden daha önce bakılması gereken ilk ve asıl dönem selef dönemidir. Metodik ve sistematik yönüyle kurumsallaşan kelamdan farklı olması ve Mutezile kelamına sert bir reaksiyoner tavrın ortaya çıkması selef döneminin genellikle akaid kapsamında değerlendirilmeye daha elverişli olabileceğini düşündürse de bu dönemi, Kelamın dînî/İslamî vasfiyla öne çıktığı ve bu anlamda özgün olarak kaldığı bir süreç olarak değerlendirmek daha uygundur. Bu noktanın açığa çıkması için Eş’arî kelamını üçlü kronolojik bir tasnife tabi tutacak olursak, Kelamın dînî/İslamî formundan uzaklaşarak akli/felsefî bir form kazanmasını daha rahat anlayabiliriz.

1. Eş’arî öncesi dönem (Selef/Öncü dönem)

2. Eş’arî sonrası, Gazali öncesi dönem (Mütekaddim/Erken dönem)

3. Gazali ve Razi sonrası dönem (Müteahhir/Geç dönem)

Bu tasnif içinde selef dönemi olarak adlandırılan sahabe ve takipçilerini içine alan tabiin ve tebe-i tabiin döneminde kelam algısı olumsuzdu. İtikadi konularda Kur'an ve 
sünnetle bağdaşmayan görüşlerin, sahabe döneminde yapılmayan tartışmaların Mutezile eliyle bu dönemde ortaya çıkması selefte kelama karşı ciddi bir reaksiyonun oluşmasına neden oldu. Dört mezhebin öncüleri olmak üzere bu dönemin önde gelen isimleri cedele kapı aralayan türden bir kelam faaliyetine karşı hep mesafeli durmuşlardı. Bu bakımdan selef için itikadi konularda tartışmasız tek otorite Kur'an ve sünnet idi. Kelami konularda da bunların sunduklarıyla iktifa etmek, cedele girmemek esastı.

Mutezile içinde kırk sene kaldığı söylenen Eş’arî’nin itizali hareketten ayrılması, ardından Ehl-i hadis ve Küllabilikle olan yakınlaşması, selefin kelama karşı geliştirdiği sert tutumun ilerleyen süreçte yumuşamasını sağladı. ${ }^{5} \mathrm{Bu}$ dönem itibariyle Kelam artık Mutezile'yi doğrudan muhatap kabul ederek cedele ve nakli delillerin yanında akli delillerle yapılan istidlal faaliyetine de sıcak bakmaya başladı. İlerleyen dönemde mütekellimlerin hem doğadan hem felsefeden deliller kullanmaları kelamın tabiat ve felsefeyle olan yakın temasını daha da artırmıştı. Eş’arî kelamı Gazali’ye kadar dînî karakteri yanında tabiî, hissî karakteriyle de öne çıkarken felsefî karakteri henüz tam olarak tezahür etmemişti. Her ne kadar Bakıllani, Bağdadi ve Cüveyni ile felsefi bir görüntü sergilese de bu dönemde felsefeyle kelam arasındaki ilişski sınırlı düzeyde kalmış, kelamın kapıları sonuna kadar felsefeye açılmamış ve felsefeye karşı koyulan mesafe belli oranda Gazali'ye kadar korunmuştu.

Kelamda ortaya çıkan metodik kaymayı Kelamın temel bilgi kaynakları üzerinden yapacağım metodik bir tasnifle daha net açıklayabilirim. Şöyle ki kelamda bilginin üç temel kaynağı selim duyu, akıl ve haber-i sadık olarak kabul edilir. ${ }^{6}$ Kelamın geçirdiği üç evreyi, üç bilgi kaynağı açısından tahlil ettiğimizde genel olarak selef döneminde sadık haberin, mütekaddim dönemde duyunun, müteahhir dönemde ise aklın ön plana çıktığını görüyoruz. Burada yaptığımız "dînî, hissî ve felsefî” şeklindeki taksim, epistemolojik düzlemde Eş'arî kelamını belirleyen ve sınırlayan ana karakteristikler üzerinden yapılan bir taksimdir.

\footnotetext{
${ }^{5}$ Yusuf Şevki Yavuz, "Eş’ariyye”, DIA, İstanbul 1995, XI/448. Nitekim Eş’arî, yaptığı kelam faaliyetinin Mutezili bir kelam faaliyeti olmadığını açıklama gereği hissetmiş ve bunun bidat ve dalalet türü bir faaliyet olmadığını "İstihsanü'l Havz fi İlmi'l Kelam" veya "el-Hass ale'l Bahs" olarak da bilinen risalesinde karşıt argümanları da sıralayarak kanıtlamaya çalışmıştır. Bk. Ebu'l Hasan Ali b. İsmail elEş'arî, Risale fi İstihsani'l Havz fi İlmi'l Kelam, Daru'l Kütübi'l İlmiyye, Beyrut 2000, s. 90, v.d.

${ }^{6}$ Teftazani, Kelam Illmi ve İslam Akaidi-Şerhu'l Akaid, çev. Süleyman Uludağ, Dergah Yayınları, İstanbul 1980, s. 106.
} 
Öyle ki selef ulemasının cedele ve te'vile karşı hep mesafeli durmaları ve her konuda nakli otorite tayin etmeleri, selefdeki Kelam algısının temel olarak dînî karakterli olduğunu ortaya koymaktadır. Mütekaddimîn kelamcılara gelince onların cevher-arazla şekillenen atomcu bakış açıları, hudûs ve imkan delilini çokça kullanmaları, kıyasü'l gaib ale'ş şahid yöntemini benimsemeleri bu dönem kelamının hissî bir karakterde olduğunu göstermektedir. Müteahhirîn kelamcıların farklı bir cevher-araz anlayışıyla mahiyet, hakikat ayrımına gitmeleri, tümdengelimci düşünme yöntemini benimsemeleri, zihnî varlık alanını haricî varlık alanına öncelemeleri, ana karakter olarak müteahhirinin de felsefî bir kelam anlayışına sahip olduklarını belgelemektedir. Formüle edecek olursak:

\section{Dînî (Selef) $\rightarrow \quad$ Hissî (Mütekaddim) $\rightarrow \quad$ Felsefî (Müteahhir)}

Bir başka ifadeyle inanç bağlamında selef için belirleyici ve öncelikli olan vahyî bilgi iken daha sonra merkeze duyusal ve felsefî bilgi hakim olmuş, bu durum neticesinde vahyin merkezî rolü zayıflamıştır. Bu çerçevede kelamın epistemolojik yapısı dînî olmanın ötesinde felsefî̀ bir hüviyete bürünmüştür. Daha açık ifade edecek olursak kelamda menkûlden mahsûsa ve ondan da ma'kûle doğru kayan ilmi ve fikri bir süreç söz konusudur.

Menkûl Bilgi (Selef) $\rightarrow$ Mahsûs Bilgi (Mütekaddimîn) $\rightarrow$ Ma'kûl Bilgi (Müteahhirîn)

Eş’arî kelamında görülen bu dönüşümü nitekim İbn Haldun, Teftazani ve Taşköprülüzade gibi kimseler fark etmiş ve açıkça dile getirmişlerdir. Bu bağlamda ismi öne çıkan ilk isim İbn Haldun'dur. İbn Haldun'un müteahhir dönem kelamına yönelttiği haklı eleştiri felsefîleşmekten öte felsefeleşen kelamın İslamî özü ve kökü itibariyle kelam olmaktan çıktığını hatırlatmaktadır.

"Müteahhirîn kelamcılarda Kelam ve Felsefenin yöntemleri birbirine karıştı. Kelamın meseleleriyle Felsefenin meseleleri iç içe girdi. Öyle ki sonuçta bu iki disiplin birbirinden ayurt edilemez hale geldi. "7

\footnotetext{
${ }^{7}$ Abdurrahman b. Haldun, Mukaddime, el-Matbaatü'l Behiyyetü'l Misriyye, Misır Tsz, s. 327. Yalnız burada dikkat çeken husus İbn Haldun'un Gazali ile Razi’yi Kelamla Felsefeyi birbirine karıştıran kelamcılar kategorisine dahil etmemiş olmasıdır. Zira İbn Haldun'e göre bu iki isim Kelam ve Felsefeye dair eserlerinde önceki kelamcılarla kendi aralarında terminolojik bir farklılık gözlemlense de konusal olarak bu iki alanı birbirine karıştırmadan incelemeyi başarmışlardır. İbn Haldun, Mukaddime, s. 327.
} 
Nitekim İbn Haldun'un çağdaşı Teftazani de müteahhir dönemin bir kelamcısı olarak benzer düşünceleri dile getirmek suretiyle sonuçta "Kelamın sem’iyyat bahisleri hariç tutulduğunda felsefeden ayırt edilemeyecek (temeyyüz) bir konuma” geldiğini ifade etmiştir. ${ }^{8}$ Teftazani bunu söylerken Kelamın felsefeleşmesini eleştirmekte mi, yoksa koşulların gerektirdiği bir zorunluluk olarak $\mathrm{m} 1$ değerlendirmektedir bu, İbn Haldun'un cümleleri kadar net değildir. Ancak mensubu olduğu ve üst düzey temsil gücü olan eserleriyle katkıda bulunduğu kelam geleneğine dair böyle bir tespit yapmış olması, Kelamın ne tür bir dönüşüm geçirdiğini göstermesi açısından önem taşımaktadır.

Taşköprülüzade, Kelam ilminde görülen değişimi epistomolojik düzlemde ele almaktadır. Ona göre konuları içine harîcî ve zihnî varlığı dahil etmesiyle Kelamın yaşadığı konusal genişleme (cihet-i vahdet-i zatiyye) kelamın dönüm noktası olmuştur. İlk dönem alimleri (selef) en yüksek gayeyi Allah'1, sıfatlarını, nübüvvet ve mead bahislerini bilmekte görmüşler, dolayısıyla eserlerinde sadece bu konulara yer vermişlerdi. Sonraki süreçte gelen alimler (mütekaddimin) bu meselelerin Metafiziğin alanına girdiğini görmüşler; ancak Metafiziğin Felsefe ile olan yakın temasının akaidi felsefeye bağlı kılacağı endişesi ile Metafiziğin zihnî/felsefî kısmına hep mesafeli durmuşlardı. Bu nedenle onlar Kelamın konularına sadece harici varlığı dahil etmişlerdi. Bunların ardından gelen alimler (müteahhirin) ise yapacakları kelam faaliyetinin mantık olmaksızın sağlıklı yürümeyeceğini düşünerek en genel şeyi, yani zihnî varlığı (mefhûm/ma'lûm) Kelama dahil etmek suretiyle ikinci defa Kelamın konu alanını genişletmişlerdi. ${ }^{9}$ Nitekim Îcî,Teftazani ve Cürcani gibi müteahhir dönemin önemli isimleri, eserlerinde Kelamın konusunun mevcûttan ma'duma her şeyi içine alan ma'lum olduğunu açıkça dile getirmişlerdir. ${ }^{10}$

Kelamın varlık ve bilgi tasavvurunda gerçekleştirdiği kırılmayla Gazali, Kelam için tam manasıyla bir dönüm noktası olmuştur. Öyle ki Gazali’nin felsefe tahsili ve

\footnotetext{
${ }^{8}$ Teftazani, Şerhu'l Akaid, s. 100.

${ }^{9}$ Taşköprîzade, Ahmed b. Mustafa, Miftahü’s Saade, nşr. Ali Dehruc, Beyrut 1998, s. 233.

${ }^{10}$ Adudüddin el-Îci, el-Mevakıf fi İlmi'l Kelam, Mektebetü'l Mütenebbi, Kahire Tsz, s. 7; Sa'düddin etTeftazani, Şerhu'l Mekasıd, Daru'l Kütübi’l İlmiyye, Beyrut 2001, I,35.
} 
felsefî̀ te'lifatıyla, ${ }^{11}$ felsefenin konularını Kelama taşıması, Gazali öncesinde Mutezile aracılığgıla felsefe ile kurulan dolaylı teması doğrudan kılmıştır. Zira artık mütekellimlerin muhatabı Mutezile değil, doğrudan Meşşai filozoflar, dolayısıyla Aristotelyen felsefe idi. Gazali'nin mantık tahsilini gerekli görmesi, mantık bilmeyenin ilmine güven duyulmayacağını belirtmesi, ${ }^{12}$ sonraki süreçte mütekellimler nazarında mantığı, dolayımında felsefeyi ve aklı öne çıkarırken, İslam kelamını dînî karakterinden de uzaklaştırmaya başladı. Razi, Amidi, Beydavi, Îcî, Cürcani ve Teftazani gibi mütekellimler Gazali'nin yaptığı felsefî açılımı metodik ve terminolojik açıdan geliştirip daha sistematik hale getirince Kelamda felsefî bir paradigmanın kök salması kaçınılmaz oldu.

İlk başlarda selefle mütekaddimin kelamcılar arasında metot anlamında bir ayrılık göze çarpsa da metodik tutum anlamında çok büyük farklılıkların olmadığı söylenebilir. Her ne kadar mütekaddimin kelamcılar tarafindan cedel, münazara, akli istidlal, temsili kıyas gibi yöntemler kullanılmış olsa da son tahlilde her iki dönemde de itikadi meselelerle ilgili merkezi otorite olarak vahiy görülüyor ve vahyin önünde ikinci bir otorite görülmüyordu. Fakat kahir ekseriyeti itibariyle mütekellimler tarafindan kabul görse de Gazali sonrası ortaya koyulan kelam türü herkes tarafindan meşrû ve makbul bir kelam tarzı olarak algılanmamıştı. ${ }^{13}$ Zira Gazali sonrası dönemde artık muhatap ve muhtevanın değişmesiyle yükselen tümdengelimci mantık anlayışı vahyin merkezi otoritesinin belirleyici rolünü azaltarak metodik anlamda selefle müteahhirin kelamcılar arasındaki makasın açılmasına neden olmuştu. Selefle mütekaddimin arasında yer yer farkl1lıklar göze çarpsa da genel olarak değerlendirildiğinde bunlar öze müteallik bir ayrılığın sebebi sayılmyordu. Ancak Gazali sonrası icra edilen kelam faaliyetiyle üretilen bilgi ve düşünceye kaynaklık eden yöntem artık özde bir ayrışmanın nedeni olarak görülüyor ve kendinden önceki kelam geleneğine de teşmil edilerek İbn

\footnotetext{
${ }^{11}$ Gazali, el-Munkız mine'd Dalale ile'l Hidaye, çev. A. Suphi Fırat, Şamil Yayınları, İstanbul 1978. s. $47,48$.

${ }^{12}$ Gazali, el-Mustasfa, I, 17.

${ }^{13}$ Watt'a göre Kelamın felsefeleşmesine, dolayısıyla kemikleşmesine ve katılaşmasına materyal sunmakla Gazali'nin kelamı zayıflattığı ileri sürülebilir ve doğal olarak Gazali'ye bu noktada eleştiriler yöneltilebilir; ancak burada Watt, bu olumsuz durumun faturasının tamamen Felsefeye veya Gazali'ye kesilmesine itiraz etmektedir. Watt, bu duraklamaya sebep olan şeyin kim ve ne olduğunun Gazali'de ya da Felsefede aranması yerine, asıl sebebin izini Gazali'nin de kendi döneminde fikhi işlerdeki gereksiz ayrıntıcı tavırlarından ve dünyaperestliklerinden yakındığı alimler gibi davranan sonraki kuşak ulemasının yaptıklarında sürülmesini önermektedir. W. Montgomery Watt, Müslüman Aydın-Gazali Hakkında Bir Araştırma, çev. Hanifi Özcan, Samsun 2003, Etüt Yayınları, s. 157.
} 
Hazm, İbn Teymiyye ve Suyûtî gibi kimseler tarafından bu yönteme şiddetle karş1 çıkılıyordu. ${ }^{14} \mathrm{Bu}$ âlimlerin ortaya koydukları eleştirilerin özellikle Kelamın zayıflayan, hatta iyiden iyiye ortadan kaybolan dînî karakteri üzerinde yoğunlaştığı dikkatten kaçırılmamalıdır.

\section{Felsefe ile Kapalı Bir Söyleme Dönüşen Kelamın Dînî Gerçeklik}

\section{Karșısındaki Konumu}

Kelamın menkûl olandan mevcût (mahsûs) olana, sonraki süreçte ise ma'kûl olana yönelmesi ve yönelişin hız kesmemesi bir yandan onu daha mücerret kılmakla felsefeye dönüştürürken, diğer yandan mutlak olma yolunda metafiziğe dönüştürmekteydi. Burada çağdaş kelamın da yüzleşmek zorunda olduğu assıl sorun, Kelamın ortaya koyduğu hâsıla, daha özünde bu hâsılaya kaynaklık eden düşünce üretim yöntem ve süreciyle Felsefe ve Metafizikten ne kadar ayrıldığı sorunudur. $\mathrm{Bu}$ yapısal sorun esas itibariyle Kelamın kavramsal alanı öncelemesi, dînî ve haricî varlık alanını da ötelemesinden kaynaklanmaktadır. Dini alandan kasıt, Kelamı dini kılan Kur'an ve sahih sünnetle kurduğu ilişkidir. Haricî varlık alanı derken de hissî (duyusal) ve insanî varlık alanını kast etmekteyiz. Zira zaman içinde hissî ve insanî olandan uzaklaşması, tarihin belli bir döneminde kelamın bütüncül bir varlık anlayışı ortaya koyamamasının en önemli nedenlerinden biridir.

Hissî alan günümüz biliminin tecrübe ve gözleme dayalı olarak incelediği fizik dünyadır. Kelamın fizikten kopuşu ve meseleleri sadece zihinde çözmeye çalışması, felsefileşmesini kaçınılmaz hale getirmiştir. Diğer yandan kanaatimizce insanî alandaki kopuşun da iki temel ayağı bulunmaktadır. Bunların ilki ahlakî (davranış) alandan kopuş iken diğeri fiilî muhatap kitleden kopuştur. Kelamın ahlakî alandan kopuşu, insanı sadece inanan ve düşünen bir canlı olarak tasavvur etmesinden kaynaklanmaktadır. Hâlbuki insan aynı zamanda eyleyen ve duygulanan bir varlıktır.

\footnotetext{
14 İbn Hazm, Eş’arî kelamcıların Allah'ın isimlerini sıfatlara dönüştürmek suretiyle yaptıkları nitelik belirleme işlemini, tevkifi bir konuda teşbih ve tecsime sapmak olarak değerlendirmektedir. Bundan ötürü onları aşırı bir tepkiyle "Lanetli Fırka" (el-Fırkatü'l Melûne) olarak görür. İbn Hazm, el-Fasl, Beyrut 1986, V, 208-210, İbnTeymiyye ve Suyûtî’nin Kelama ve kelamcılara yönelik eleştirileri için bk. İbn Teymiyye, Derü Tearüzi'l Akli ve'n Nakl, s. 121-131, Daru'l Hadis, Kahire 2006; Celaleddin es-Suyûtî, Savnü'l Mantık ve'l Kelam an Fenni'l Mantık ve'l Kelam, Misır 1946, s. 57-70.
} 
İnsanın eylem yönü Fıkıha, duygu yönü de Tasavvufa havale edilince Kelam, insanın ontolojik bütünlüğüne uygun bir varlık ve bilgi sistemi olmaktan uzaklaşmıştır.

Kelamın içe kapanmasına neden olan bir başka unsur fiilî muhataplık ilişkisinin ortadan kalkmasıdır. Güncellenen ve yenilenen muhataplık ilişkisi kelamı ayakta tutan, zihne kapanmaktan alıkoyan önemli bir boyuttur. Kelamın tarihsel süreçte, diyalektik kurduğu güncel ve değişken muhatap kitleyi kaybetmesi, onu kendi içine kapanan bir söylem ve sisteme dönüştürmüştür. Mütekaddim dönemde başka firkaların yanında özellikle Mutezile ve Şia’yı muhatap alan mütekellimler, sonraları Meşşai ve İşraki filozofları karşılarına alarak özellikle Gazali ve Razi'nin girişimleriyle ortaya çıkan itikadi tehdit unsurlarını belli oranda etkisiz hale getirmişlerdi. Bunların tamamen olmasa da büyük ölçüde ortadan kalkmasıyla oluşan güvenli ortam, mütekellimler nezdinde felsefî konulara olan ilgi ve merakı artırmıştı. ${ }^{15}$

Ancak kelamcıların felsefeye duydukları yoğun ilgi ilerleyen süreçte Kelamı kapalı bir söylem olmakla karşı karşıya getirecektir. Nitekim Kelamın cedeli karakterinden beslenen diyalojik ve dinamik dili bir süre sonra monolojik ve elit bir dile dönüşmeye başladı. Kelamın soyut ve kapalı bir dile dönüşmesini, fiili hasımlarının ortadan kalkması neticesinde kendisine muhayyel hasımlar oluşturması yanında, artık kendisini İslam inancının üst (koruma) ve tek şemsiyesi olarak algılamaya başlamasıyla, kendiliğinden gelişen bir süreç olarak da yorumlamak mümkündür. Kelamın adeta şiir ve tasavvufun dili gibi kendi kendine yeter bir söyleme dönüşmesi zaman içinde Kelamı Kur'an ayetlerini dahi sadece kendi söylem düzeyinde tartışan, dolayısıyla sunmak zorunda olduğu dış kanıtların argümantasyon kaynağının da kendisi olduğuna inandıran bir ilmî tavır alışa sürüklemiştir. ${ }^{16}$

Dînî karakterini göz önünde bulundurarak ifade edecek olursak Kelamın özgün temel sorunu 'dînî gerçeklik’ten kopuşudur. Dînî gerçeklikten kastımızın, dayattı̆̆ 1 gerçeklikle zihni aşan ve kuşatan duyusal, olgusal (muhatap) ve ahlakî unsurları içine alan, dinin temel kaynaklarında referans varlık dünyası olarak sunulan "hissî ve insanî gerçeklik alanları" olduğunu belirtmeliyiz. Ayrıca bu tanımlama içinde zihni ve zihinsel olanı, dînî gerçeklik alanının dışında görmediğimizi de ifade etmek istiyoruz. Yukarıda

\footnotetext{
${ }^{15}$ M. Sait Özervarlı, İbn Teymiyye'nin Düşünce Metodolojisi ve Kelamcılara Eleştirisi, İSAM Yayınları, İstanbul 2008, s. 84.

${ }^{16}$ Tatar, "Kelami Söylemin Monolojik Karakteri”, s. 77, 78.
} 
sözü edilen asıl ve gerçek varlık alanlarının dine muhatap olmanın kriteri sayılan akla, insan olmanın gereği olan düşünceye konu edilmelerinin bizzat vahiy tarafindan istenmesi zihnin de dinin dışında görülemeyeceğinin kanıtıdır.

$\mathrm{Bu}$ bakımdan İbn Teymiyye'nin düşünce metodolojisi içinde akıl-nakil karşıtlığını giderme adına önerdiği delil anlayışı, aklın nakil karşısında değil nakille aynı düzlemde konumlandırılması gerektiğine vurgu yapar. İbn Teymiyye açısından aklî ve naklî delillerin aynı kategori içinde yer almalarında hiçbir sakınca yoktur. Ona göre delil anlayışı kelamcıların yaptığı gibi aklî-naklî şeklinde karşıtlık çağrıştıran bir tarzda değil, bunun yerine aklı da nakli de dinin çatısı altında birleştiren bir tarzda kurgulanmalıdır. ${ }^{17}$

$\underline{\text { Kelamcilar }}$

Delil

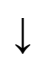

Aklî / Naklî

\section{İbn Teymiyye}

Delil

Şer'̂̂ / Bid'î

\section{Aklî/Naklî}

Kelamın İslam kelamı olması ve bu sınırlar içinde kalması mücerret akılla değil nakil yörüngeli bir çerçevede fikir ve bilgi üretmesine bağlıdır. Aksi takdirde Kelamın felsefî̀ ve metafizik bir hüviyete bürünmesi kaçınılmazdır. Allah'ın zatı, sıfatları ve mümkünlerin hallerinden bahsederken Kelamın tarifinde dile getirilen "İslam kanunu" kayd1, Kelamın Felsefe ve Metafiziğe dönüşmesini engellemek, buna kapı aralamamak adına koyulan önemli ihtirazi bir kayıttır. ${ }^{18} \mathrm{Bu}$ açıdan değerlendirildiğinde Kelam mutlak bir akıldan hareketle çıkarsanan kanunlar üzere değil, İslam'ın öngördüğü kanunlar üzere varlık ve bilgi hakkında konuştuğunda Felsefe ve Metafizik olmaktan ayrilır.

\footnotetext{
${ }^{17}$ Özervarl, İbn Teymiyye'nin Düşünce Metodolojisi ve Kelamcılara Eleştirisi, s. 88.

${ }^{18}$ Ali b. Muhammed eş-Şerif el-Cürcani el-Hüseyni el-Hanefi, Kitabü't Ta'rifat, thk. Muhammed

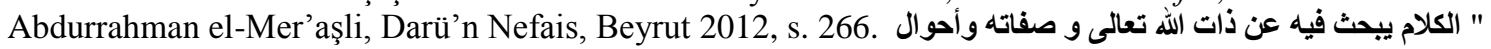
المكنات من المبإ و المعاد على قانون الإسلام."
} 
Özetleyecek olursak Kelamın üç temel bilgi kaynağını birbirinden bağımsız işleyen süreçler olarak görmek hatalı bir yaklaşım örneğidir. Bu bilgi kaynakları Kelamın epistemolojik temellerini oluşturması bir yana, özü itibariyle ontolojik bütünlüğünü sağlayan ve koruyan araçlardır. Ancak naklin duyu, duyunun da akıl karşısında ötelenmesi, Kelamın ontolojik bütünlüklü bir sistem olmasının önüne geçmiştir. Geç dönemde Kelamın konusal ve kavramsal düzeyde felsefî bir derinlik yakaladığı bir gerçektir; ancak bu durumu kelamın mutlak anlamda lehine bir gelişme olarak kaydetmek zordur. Çünkü Kelamın Felsefe ile kendisine has rezervlerini korumadan kurduğu temas onun nakilden uzaklaşarak dînî, duyudan uzaklaşarak da fizikî ve insanî karakterinin çözülmesine neden olmuştur.

Sonuç itibariyle Kelam bu sebeplerden ötürü bütüncül bir varlık anlayışı tesis edememiştir. İdeal anlamda Kelam, birini diğerine tercih eden değil, duyu ve akıl ile sürekli iletişim halinde işleyen nakil merkezli varlık ve bilgi sistemine ihtiyaç duyan bir disiplindir. Nitekim Kur'an'ın bilgi ve inanç sistemi içinde ikiye ayırdığ 1 şehadet (fizik) ve gayb (metafizik) aleminden şehadet alemi, gaybî alemin ve meselelerin anlaşılması noktasında Kur'an'a dayalı yürütülen bir kelam faaliyetinin en önemli dayanağıdır. Merkezinde naklin bulunduğu bu iletişim halini şu şekilde sembolize edebiliriz:

$$
\text { Duyu } \leftrightarrow \quad \text { Nakil } \leftrightarrow \quad A k l l
$$

İslam kanunu üzere konuşmanın zorunlu gereği olan nakilden bağımsız düşünce ve bilgi üretiminin imkanı, Cüneyd-i Bağdadi'nin bahsettiği türden aklın aklen tükendiği, aklın akıl içinde düştüğü ve farkına varamadığı paradoksal bir halin makûliyeti oranındadır. Cüneyd, kelama dalmış, “(nazari) delillerle Allah’ı muhdes sıfatlardan ve her türlü eksiklikten tenzih eden" mütekellimler topluluğuyla karşılaştı̆ında şöyle demişti: "Eksikliğin olmasının imkansız olduğu yerde, var olması mümkün olmayan eksikliği inkar etmek bir eksikliktir.,"19

Asıl itibariyle Allah hakkında ortaya çıkan bütün spekülasyonlar vahyin değil, vahiyden bağımsız işleyen salt akıl aracıllğıyla elde edilen akli kanunlara dayanarak bir Allah anlayışı ortaya koymak isteyenlerin eseridir. Spekülatif Allah anlayışları işlevsel olamazlar; bunlar sadece zihinde soyut bir kavram olarak var olan bir Allah tasavvuru inşa edebilirler. Hâlbuki vahyin bize tanıttığı Allah, duyu, düşünce ve duygu

\footnotetext{
${ }^{19}$ İbn Haldun, Mukaddime, s. 327, 328.
} 
dünyamızın her aşamasında varlığını hissetiren, "bize bizden daha yakın"20 olan bir varlıktır. Dolayısıyla Kur'an en başta Allah'a iman gibi inanç esaslarını anlatırken "spekülatif ve kavramsal" bir söylem geliştirmediği gibi, sadece insanın aklına hitap eden bir iman ve insan anlayışı da öngörmemektedir. ${ }^{21}$

\section{Sonuç}

Eş’arî kelamı ölçeğinde ele alındığında İslam kelamının Eş’arî’ye kadar nakil yörüngeli, Eş’arî'den sonraki süreçte duyusal, Gazali sonrasında ise kavramsal bir form kazandığı görülmektedir. Kavramsal düşünme biçiminin sonuçta ortaya çıkaracağı teolojik sistem de kavramsal olacaktır. İnancın aklî olup olmaması inancın kavramsal düzleme taşınmasını gerektirebilir; ancak buradaki sorun meselenin kavramsal düzleme taşınması değil teolojik konuların tamamen kavramsal bir düzleme indirgenmesidir. Bir diğer tabirle asıl sorun bu indirgeme işleminin Kelamın duyu, akıl ve haber-i sadık şeklindeki üçlü bilgi kaynaklarından öncelikle haber-i sadık daha sonra da duyunun ihmal edilişine yol açmasıdır.

Usûlü’d Din olması açısından bakıldığında Kelamın kurucu disiplin olma vasfi, varlığını ikame ve idame ettiren köklerine bağlılığı oranında geçerli olabilir. Mahiyet ve muhtevasının değişmesiyle asıl ve özgün konumundan uzaklaşan ve varlık nedeni olan temellerinden kopan bir kelamın kurucu olma hüviyetinden bahsetmek reel karşılı̆̆ olmayan bir söylemi dillendirmek ve muhayyel bir gerçeğe yaslanmaktan farksızdır. Bunu önlemenin yolu Kelamın geç dönemde varlık ve bilgi tasavvurunu çevreleyen kavramsal ve soyut çizginin hayatın ve insanın somut gerçekleriyle örtüşen bir sistem olarak yeniden kurgulamasından, bir başka deyişle kendisini İslam kelamı yapan köklerine dönmesinden geçmektedir. $\mathrm{Bu}$ noktada konunun kelamcılar tarafından tartışılması Kelam ilminin kurucu disipliner yapısının temadisi açısından varoluşsal bir ihtiyaçtır. Kelamın kurucu disiplin olma iddiası köklerine bağlı özgünlüğü yanında, olgusal gerçekliğe ve dinamikliğe uygun düşen bir düşünce ve bilgi sistemi olup olmadığı ile yakından ilgilidir. Bu nedenle Kelamın güncel itikadi sorunlara dair

\footnotetext{
${ }^{20}$ Kaf $16 / 50$.

${ }^{21}$ Alparslan Açıkgenç, , Bilgi Felsefesi, İnsan Yayınları, İstanbul 1992, s. 238.
} 
perspektifi sadece zihinden ve zihinsel olandan hareketle belirlenemez. Usûlü'd Din olmanın ilk ve temel anlamı her şeyden önce vahiy merkezli bir perspektifi öngörmektedir. Bir diğer anlamıyla da vahyî bilginin 1şı̆̆ında, yaşanılan gerçekliğe uygun bir düşünce yöntemini tesis etmektir. Bir bütün halinde ifade edecek olursak "Doğa Kelamı” veya "Entelektüel Kelam”ın dînî ve inşaî hüviyetlerinden söz edilecekse bunun ancak "Kur'an Kelamı” ile sürekli iletişim halinde olan bir süreçle mümkün olabileceği unutulmamalıdır.

\section{Kaynakça}

Açıkgenç, Alparslan, Bilgi Felsefesi, İnsan Yayınları, İstanbul 1992.

Cürcani, Ali b. Muhammed el-Hüseyni el-Hanefi, Kitabü't Ta'rifat (tah. Muhammed Abdurrahman el-Maraşli), Darü'n Nefais, Beyrut 2012.

Eş’arî, Ebu'l Hasan Ali b. İsmail, Risale fi İstihsani'l Havz fi İlmi'l Kelam, Daru'1 Kütübi'l İlmiyye, Beyrut 2000.

Gazali, Ebu Hamid Muhammd b. Muhammed, el-Munkız mine'd Dalale ile'l Hidaye çev. A. Suphi Fırat, Şamil Yayınları, İstanbul 1978. , el-Mustasfa çev. Yunus Apaydın, Klasik Yayınları, İstanbul 2007.

Hayâlî, Ahmed, Haşiyetü'l Hayâlî ala Şerhi'l Akaid (Mecmuatü'l Havaşi elBehiyye ala Şerhi'l Akaid en-Nesefiyye'nin Kenarında-neşr. Abdülkerim), elMektebetü'1 İslamiyye.

İbn Haldun, Abdurrahman, Mukaddime, el-Matbaatü'l Behiyyetü'l Misriyye, Misir Tsz.

İbn Hazm, el-Fasl, Beyrut 1986.

İbn Teymiyye, Derü Tearüzi’l Akli ve'n Nakl, Daru'l Hadis, Kahire 2006.

Îcî, Adudüddin, el-Mevakıffi İlmi’l Kelam, Mektebetü’l Mütenebbi, Kahire Tsz.

İzutsu, Toshihiko, Kur'an'da Allah ve insan çev. Süleyman Ateş, İstanbul Tsz.

Kestelî, Muslihuddin Mustafa, Haşiyetü'l Kesteli ala Şerhi'l Akaid, Salah Bilici Kitabevi, İstanbul Tsz.

Özervarl1, M. Sait, İbn Teymiyye’nin Düşünce Metodolojisi ve Kelamcılara Eleştirisi, İSAM Yayınları, İstanbul 2008.

Suyûtî, Celaleddin, Savnü'l Mantık ve'l Kelam an Fenni'l Mantık ve'l Kelam, Misir 1946.

Taşköprîzade, Ahmed b. Mustafa, Miftahü’s Saade neşr. Ali Dehruc, Beyrut 1998. 
Tatar, Burhanettin, “Kelami Söylemin Monolojik Karakteri”, s. 77, Tezkire, S. 31, 32, Mart/Haziran 2003.

Teftazani, Sa'düddin, Şerhu'l Mekasıd, Daru'1 Kütübi'l İlmiyye, Beyrut 2001.

........ Kelam İlmi ve İslam Akaidi-Şerhu'l Akaid, çev. Süleyman Uludağ, Dergah Yayınları, İstanbul 1980.

W. Montgomery Watt, Müslüman Aydın-Gazali Hakkında Bir Araştırma, çev. Hanifi Özcan, Etüt Yayınları, Samsun 2003.

Yavuz, Yusuf Şevki, “Eş’ariyye”, DİA, İstanbul 1995, XI, 448. 